\title{
多質点弾塑性系の最大層間変形角速度応答 \\ MAXIMUM INTERSTORY VELOCITY OF ELASTO-PLASTIC MULTI-DEGREE OF FREEDOM SYSTEM DUE TO SEVERE EARTHQUAKE
}

\author{
上村 健 二*1, 井上一朗*2 \\ Kenii UEMURA and Kazuo INOUE
}

\begin{abstract}
It has been pointed out that the strain rate affects on the ductility of mild steel. For the steel moment frame of the strong column type, the strain rate at the end of the beam flange is determined by the rotational velocity. The velocity is almost equals to the interstory velocity when the beam is in the plastic region. In this paper, the various elasto-plastic multi-degree of freedom systems are analyzed with the parameters of input motions, number of story, story height and hysteretic characteristics. The maximum interstory velocity is about $0.1 \mathrm{rad} / \mathrm{s}$ and $0.2 \mathrm{rad} / \mathrm{s}$ at most. To estimate the maximum interstory velocity, the velocity is examined theoretically and the estimate method is proposed. The velocity of the theoretical estimation is roughly equals to that of the dynamic responses.
\end{abstract}

Keywords : strain rate, interstory velocity, multi-degree of freedom system, seismic response analysis 歪速度, 層間変形角速度, 多質点系, 地震応答解析

1. 序

鋼材の破壊勒性に及ほすす歪速度の影響が指摘され ${ }^{21}$, 動的載荷実 験 ${ }^{3 \sim 5)}$ や速度応答の数值解析 $\left.{ }^{6}, 7\right)$ が行われている. 地震時に生じる 梁端の歪度は梁端回転角と関係づけられ, 梁端の歪速度は梁端回 転角速度の関数となる ${ }^{8)}$ 。 ラーメン構造の梁端部を対象とし, 図1 に示すように微小時間に扔ける梁端の塑性ヒンジ回転角増分を $\Delta \theta$, 層間変形角増分を $\Delta R$ とする. 図1(a)のように梁の両端にほぼ同時 に塑性ヒンジが形成される場合は, 梁端の回転角速度はほほ層間 変形角速度に等しい. また梁の中間荷重が大きく，図1(b)のように まず一方の梁端に塑性ヒンジが形成される場合は，この塑性ヒン ジの回転角速度は層間変形角速度の 1.5 倍になる. どちらの場合も 梁端の歪速度は層間変形角速度に直接支配されることになる。し たがって，梁端に生じる歪速度の最大值を把握するためには，層

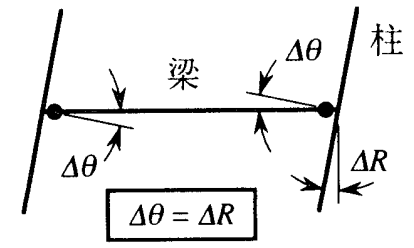

(a)両端にヒンジが生じる場合

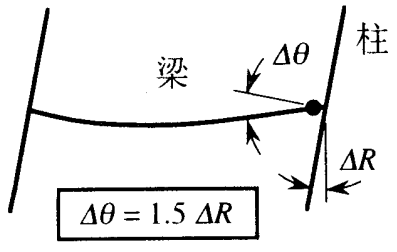

(b)片端にヒンジが生じる場合
図1層間变形角増分と梁端回転角増分の関係
間変形角速度の最大值を求める必要がある.

本論では, 地震時に発生する最大層間変形角速度を把握するこ とを目的として, 層数 ・階高 - 層の復元力モデル · 入力地震動を パラメータとするせん断形多質点系の弾塑性地震応答解析を行 い, 最大層間変形角速度に関して整理を行う。また, 最大層間变 形角速度の評価式を理論的に誘導し，応答解析結果と比較する。

\section{2. せん断形多質点系の弾塑性地震応答解析}

\section{1 復元力特性}

復元力モデルとしては，図2に示寸完全弾塑性型とTri-Linear型の 2 種類を用いる。完全弾塑性型は梁のスパンが短い場合に相当 し, Tri-Linear型は梁スパンが長く，かつ Bauschinger効果を考慮し た場合に相当する。図2の復元力モデルに関する諸量の設定条件は 次のとおりである。

[1] 各層の階高, 質量は等しい.

[2] 1 次設計用の標準せん断力係数 ${ }_{1} C_{0}=0.2$ に対する弾性層間変 形角は1/200rad.である。

[3] Tri-Linear 型の第1折れ曲がり点の層せん断力は保有水平耐力 の2/3，2次剛性は初期剛性の0.3倍とする.

[4] 保有水平耐カレベルに対応するベースシャー倸数 $C_{B U}$ (以下,

本論文は，文献1)に発表したものに解析デー夕㧍よび，最大㕌間変形角速度の觯価式を追加したものである。

*1 川崎製鉄侏建材センター鋼構造研究所 研究員・工修 Research Engineer, Steel Structure Research Labs., Construction Materials Center,

Kawasaki Steel Corp., M. Eng.

*2 京都大学大学院工学研究科生活空間学専攻 教授. 工博 $\quad$ Prof., Dept. of Architectural and Environmental Design, Graduate School of Engineering, Kyoto University, Dr. Eng. 
終局ベースシヤー係数）は，2次設計用の標準せん断力係数 を 1.0 として(1)式によって定め, 各層の保有水平酎力の分布

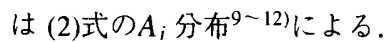

$$
\begin{aligned}
& C_{B U}=R_{t} D_{S} \\
& A_{i}=1 / \sqrt{\alpha_{i}}, \alpha_{i}=\sum_{j=i}^{N} m_{j} / M
\end{aligned}
$$

ここで, $m_{i}: i$ 層の質量, $M:$ 全質量.（1)式における振動特性係数 $R_{t}$ の決定に必要な基本固有周期 $T$ は，条件[1]，[2]扔よび(2)式から 次式で与えられる13).

$$
T^{2}=\frac{2 \pi^{2} h R_{a}(N+1)(2 N+1)}{3 Z R_{t} C_{0} g \sum_{i=1}^{N} \sqrt{\alpha_{i}}}
$$

ここで, $h:$ 階高, $R_{a}: 1$ 次設計用の標準せん断力係数に対する弾性 層間变形角 $\left(R_{a}=0.005\right), N$ : 層数, $Z$ : 地域係数 $(Z=1)$.

(1) 式における振動特性係数 $R$, の算定には第 2 種地盤 $\left(T_{c}=0.6\right)$ に対応するものを用い, 次式のように基本固有周期 $T$ について場 合分けして与える.

$$
\begin{array}{ll}
T \leq 1.6 T_{c} \text { の場合 : } & R_{t}=1 \\
T>1.6 T_{c} \text { の場合 }: & R_{t}=\frac{1.6 T_{c}}{T}
\end{array}
$$

$T \leq 1.6 T_{c}$ の場合，(3)，(4)式より，Tは次式のように得られる。

$$
T=2 \pi \sqrt{\frac{h R_{a}(N+1)(2 N+1)}{6 Z_{1} C_{0} g \sum_{i=1}^{N} \sqrt{\alpha_{i}}}}
$$

$T>1.6 T_{c}$ の場合，(3)，(5)式より，Tは次式のように得られる.

$$
T=\frac{\pi^{2} h R_{a}(N+1)(2 N+1)}{2.4 T_{c} Z{ }_{1} C_{0} g \sum_{i=1}^{N} \sqrt{\alpha_{i}}}
$$
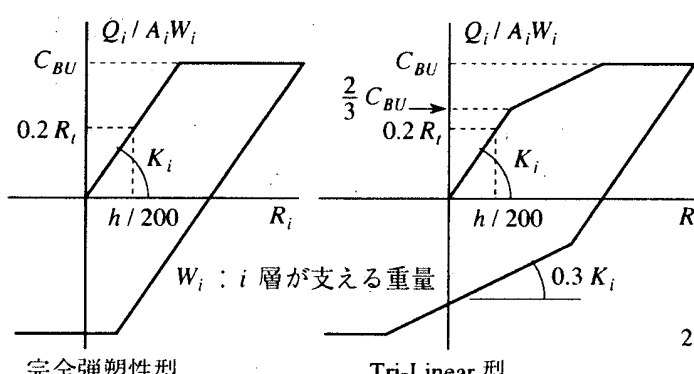

図2 層せん断力ー層間変形角関係の復元力モデル

表1 解析系の固有周期と終局ベースシヤー係数

\begin{tabular}{|r|c|c|c|c|c|}
\hline \multirow{2}{*}{$N$} & \multirow{2}{*}{$T(\mathrm{~s})$} & \multirow{2}{*}{$T_{1}(\mathrm{~s})$} & \multirow{2}{*}{$T_{2}(\mathrm{~s})$} & \multicolumn{2}{|c|}{$C_{B U}$} \\
\cline { 5 - 6 } & & & & $D_{S}=0.3$ & $D_{S}=0.5$ \\
\hline 1 & 0.635 & 0.635 & & 0.300 & 0.500 \\
\hline 2 & 0.768 & 0.775 & 0.314 & 0.300 & 0.500 \\
\hline 3 & 0.886 & 0.909 & 0.358 & 0.300 & 0.500 \\
\hline 4 & 1.024 & 1.049 & 0.406 & 0.270 & 0.450 \\
\hline 5 & 1.231 & 1.237 & 0.474 & 0.234 & 0.390 \\
\hline 6 & 1.439 & 1.447 & 0.551 & 0.200 & 0.334 \\
\hline 8 & 1.856 & 1.869 & 0.707 & 0.155 & 0.259 \\
\hline 10 & 2.274 & 2.291 & 0.863 & 0.127 & 0.211 \\
\hline 12 & 2.692 & 2.714 & 1.021 & 0.107 & 0.178 \\
\hline 16 & 3.529 & 3.560 & 1.336 & 0.082 & 0.136 \\
\hline 20 & 4.367 & 4.511 & 1.691 & 0.063 & 0.105 \\
\hline
\end{tabular}
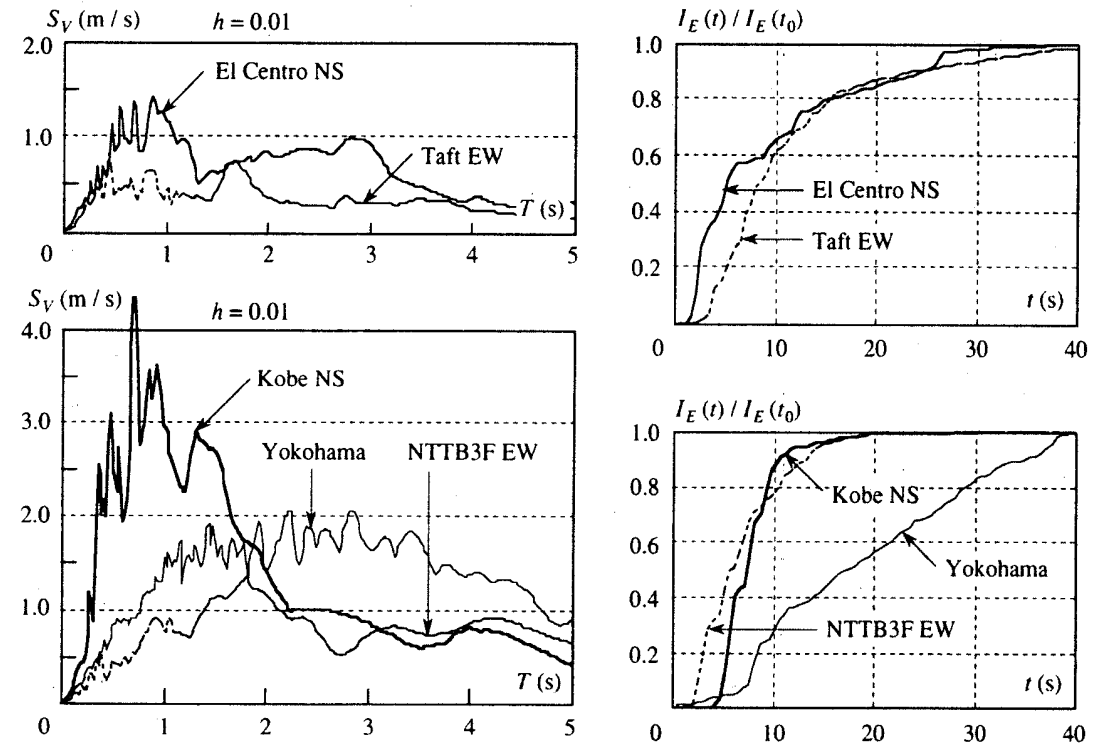

(7)式を(5)式に代入して $T>1.6 T_{c}$ の場合の $R_{t}$ が得られる.

$D_{S}=0.3,0.5$, 階高 $h=4 \mathrm{~m}$ の場合について, 解析対象とした層 数と対応する基本固有周期 $T$, 固有值解析による1次と 2 次の固有 周期 $\left(T_{1}, T_{2}\right)$ ，終局ベースシヤー倸数 $C_{B U}$ をまとめて表1に示 す. $D_{S}$ 值のレベルは 0.3 と 0.5 を採用し，一部 0.25 と弾性系について

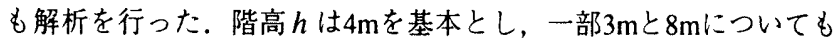
解析を行った。

\section{2 入力地震動と応答解析}

入力地震動は表 2 に示す 5 波である．各地震動の擬似速度応答ス ペクトル $S_{V}$ と最初の 40 秒までの加速度パワー $I_{E}$ の時刻歴を図 3 に 示す. $I_{E}$ は次式で定義される ${ }^{14)}$.

$$
I_{E}(t)=\int_{0}^{t}(\ddot{y})^{2} \mathrm{~d} t
$$

ここで, $\ddot{y}$ は時刻 $t$ での地動加速度であり， $I_{E}$ はその二乗積分值で ある，図3は全継続時間 $t_{0}$ に対する全加速度パワー $I_{E}\left(t_{0}\right)$ で無次元 化している.

入力地震動の強さは，損傷に寄与する地震入力エネルギー $E_{d n}$ の 速度換算値 $V_{d m}$ がある一定值になるように決定している。ここで, $E_{d m}$ と $V_{d m}$ は次式で定義される。

$$
\begin{aligned}
E_{d m} & =\left(E_{D p}+E_{\ell}\right)_{\max } \\
V_{d m} & =\sqrt{\frac{2 E_{d m}}{M}}
\end{aligned}
$$

上式で， $E_{D p}$ は塑性履歴による吸収エネルギ一， $E_{e}$ は弾性振動エネ ルギーで歪エネルギーと運動エネルギーの和である， $V_{d m}$ は $150 \mathrm{~cm} /$

\section{表2 入力地震動}

\begin{tabular}{|c|l|c|c|c|}
\hline 加速度記録 & \multicolumn{1}{|c|}{ 略称 } & 最大加速度 & 継続時間 & 解析時間 \\
\hline EI Centro 1940 NS & El Centro NS & $341.7 \mathrm{Gal}$ & $53.7 \mathrm{~s}$ & $30 \mathrm{~s}$ \\
\hline Taft 1952 EW & Taft EW & $175.9 \mathrm{Gal}$ & $54.4 \mathrm{~s}$ & $30 \mathrm{~s}$ \\
\hline 神戸海洋気象台 1995 NS & Kobe NS & $821.0 \mathrm{Gal}$ & $30.0 \mathrm{~s}$ & $20 \mathrm{~s}$ \\
\hline NTT神戸駅前ビルB3F 1995 EW & NTTB3F EW & $153.5 \mathrm{Gal}$ & $50.4 \mathrm{~s}$ & $20 \mathrm{~s}$ \\
\hline 横浜表面波 (人工地震) & Yokohama & $312.0 \mathrm{Gal}$ & $40.0 \mathrm{~s}$ & $40 \mathrm{~s}$ \\
\hline
\end{tabular}

図3 入力地震動の擬似速度応答スペクトルと加速度パワーの時刻歷 
$\mathrm{s}$ 基本とし，一部 $225 \mathrm{~cm} / \mathrm{s}, 300 \mathrm{~cm} / \mathrm{s}$ の場合も解析を行った.

減衰は1次，2次ともに減衰定数が 0.01 の Rayleigh型としている.

\section{3 地震応答解析結果}

層間変形角速度応答の最大值 $V_{R}$ に関する数値計算結果を図 4 図7に示す，図4では各層の速度応答值および平均值をプロットし ているが, 図5 〜図7では, 各層の速度応答の平均值だけを比較し
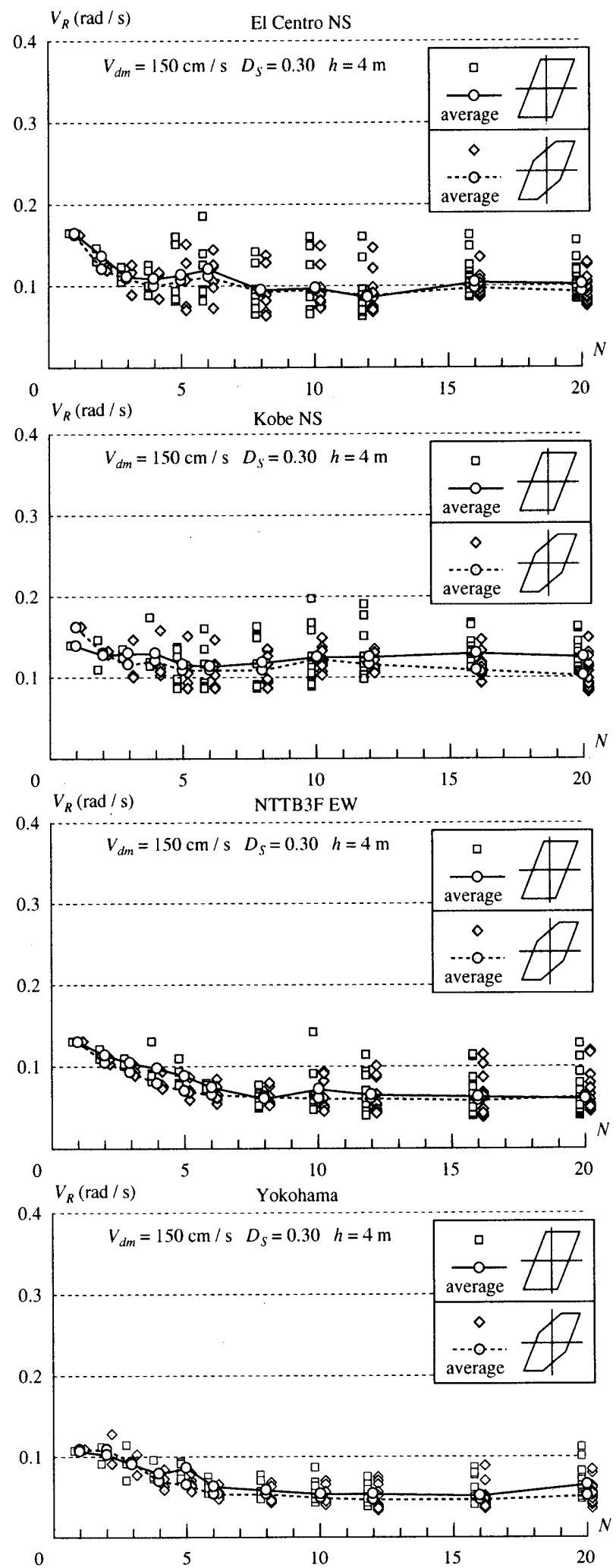

図4 各層の最大層間変形角速度の応答と平均値
ている，ただし，Taft EWに対する応答值はEl Centro NSの応答值と ほほ同じでありここでは割爱した。なお，各解析結果の解析パ ラメー夕は，図中に示している。図 8, 図9はそれぞれ $D_{S}=0.3$, $D_{S}=0.5$ の 1 質点系の最大速度の発生点と時刻を，その前後の履歴 曲線上にプロットしたものである。

図4一図9に示す結果から，下記の特徵的事項が指摘される。

1) 最大層間変形角速度 $V_{R}$ は復元力特性に影響されない.ただし $V_{R}$
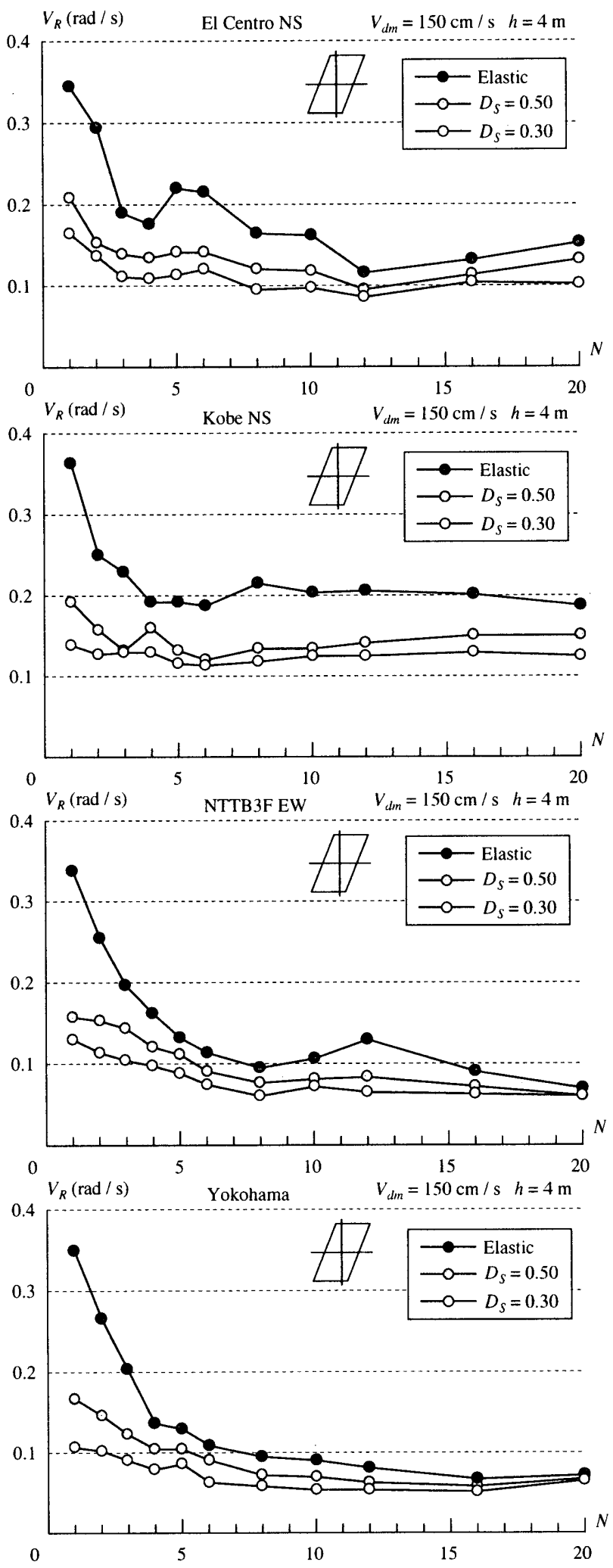

図5 最大層間变形角速度の平均值の比較（耐カレベルの影響） 
の高さ方向分布については，完全弾塑性型の場合よりTri-Linear 型の方がばらつきは小さい（図4）。

2）系の耐力レベルが大きくなると $V_{R}$ も大きくなる（図5）.

3) $V_{R}$ は損傷に寄与する地震入力エネルギーにほほ比例して大きく なる（図6）。

4) 層数の増加に伴って $V_{R}$ は漸減する傾向にある。ただし，5層以 上ではほぼ一定とみなせる（図4～図7）。

5）階高が大きくなると若干 $V_{R}$ は減少する傾向にある（図7）.

6) 加速度パワーが短時間に急激に増大寸る地震の方が, 徐々に増 大する地震に比べて大きな $V_{R}$ を発生させる（図3～図5）.

7) 系の耐力レベルが $D_{S}$ 值で $0.3 \sim 0.5$ の場合, 損傷に寄与する地震

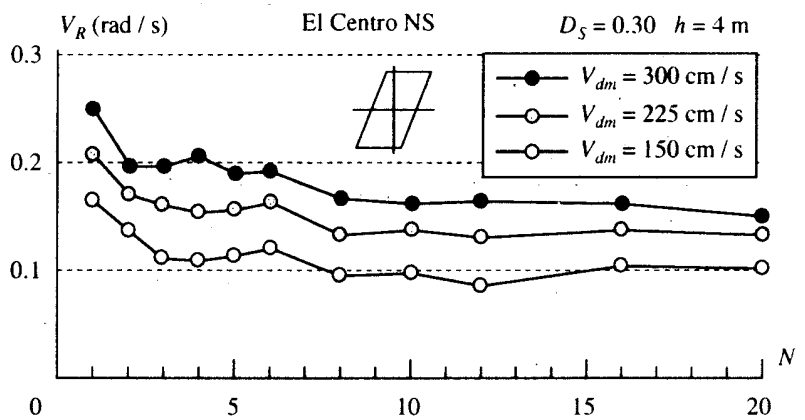

図6 最大層間変形角速度の平均値の比較（入カレベルの影響）
入力エネルギーの速度換算値が $150 \mathrm{~cm} / \mathrm{s}$ の入力レベル（第 2 種地 盤に相当）に対する $V_{R}$ の值は平均で $0.1 \mathrm{rad} / \mathrm{s}$ 程度であり，高さ 方向の応答のばらつきを含めても高々 $0.2 \mathrm{rad} / \mathrm{s}$ 程度である（図4 一図7).

8) $V_{R}$ は，その前の半サイクルで塑性化している状態，すなわち弾 性歪エネルギーが最大になった後，さらに大きな塑性履歴を受 ける際に発生する場合が多い（図8，図9）。

以上, 最大層間变形角速度応答に関する解析結果について述べた が, 鋼材の破壊勒性に関しては塑性化状態での最大值に着目する必 要がある．図 8 と図 9 を比較すると, $D_{S}$ 値が大きくなるはど $V_{R}$ は弾 性域で生じることが多い，そこで，塑性化状態における最大層間変

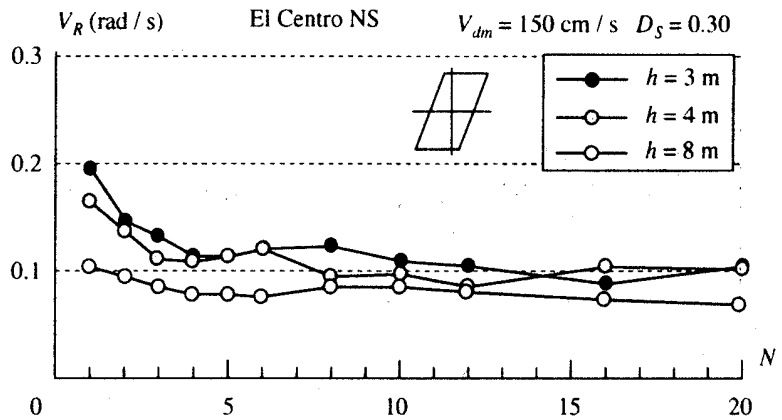

図7最大層間変形角速度の平均値の比較（階高の影響）
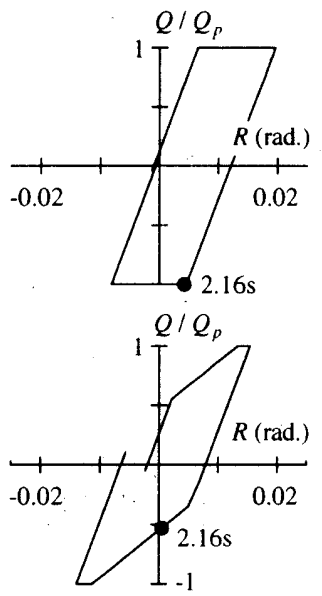

El Centro NS
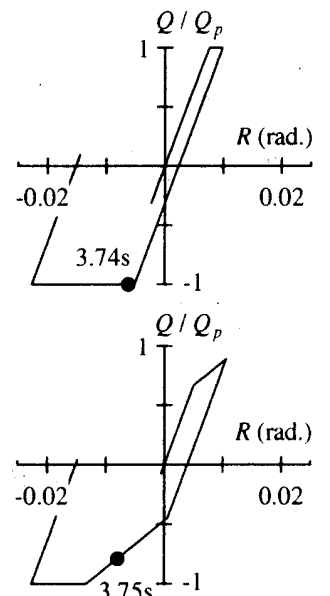

Taft EW
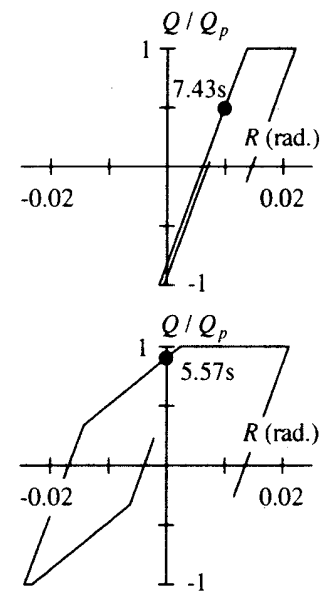

Kobe NS
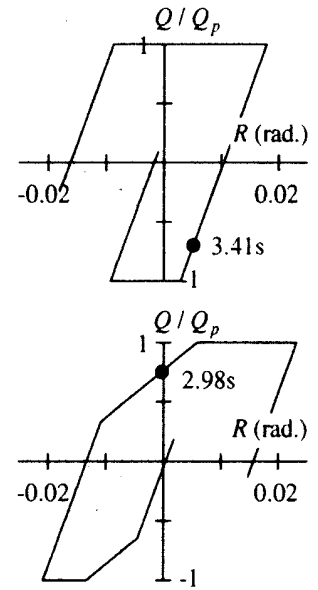

NTTB3F EW
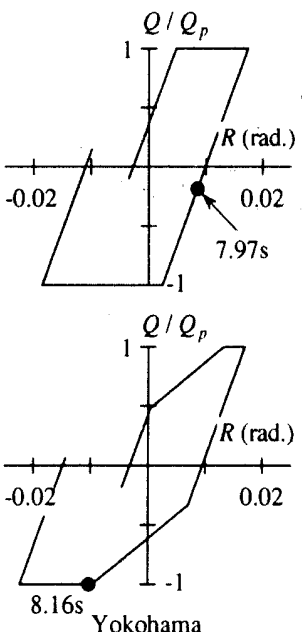

図8 1質点系の最大速度の発生点と時刻 ( 印; $D_{S}=0.3$ の場合)
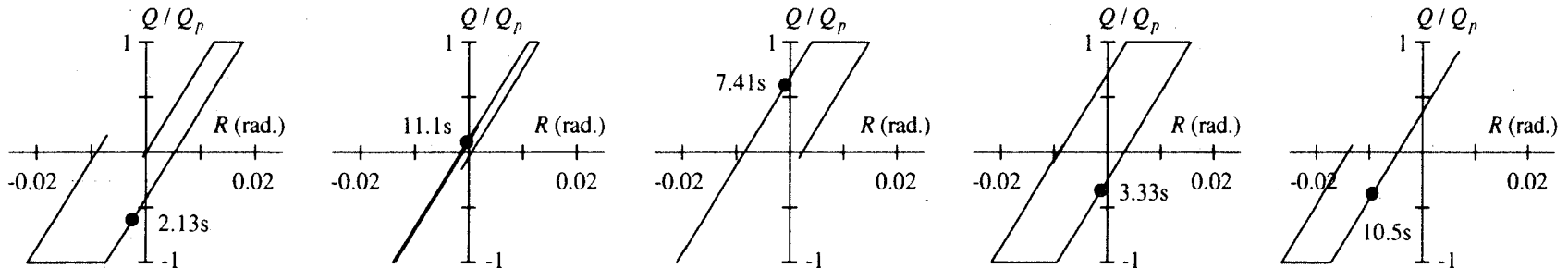

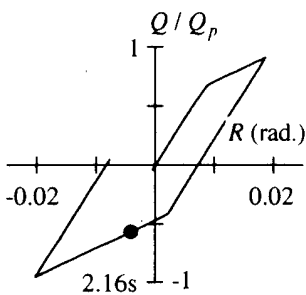

El Centro NS

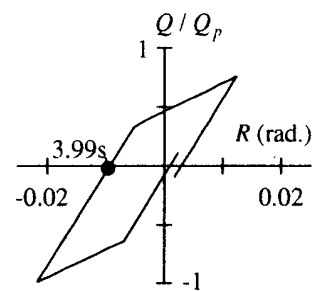

Taft EW

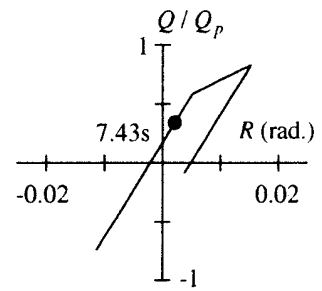

Kobe NS

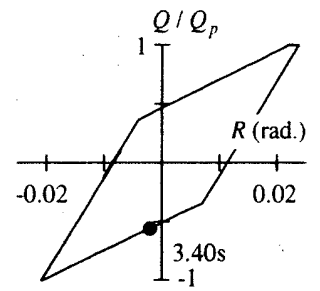

NTTB3F EW

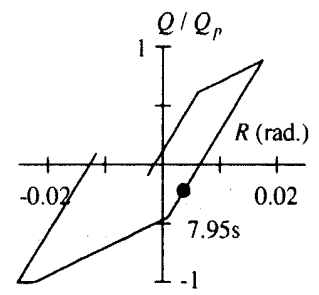

Yokohama

図9１質点系の最大速度の発生点と時刻（○印； $D_{S}=0.5$ の場合） 
形角速度 $V_{R p}$ に関しても整理を行った。 $V_{R p}$ に関する数値計算結果 を図 10, 図 11 に示す. 塑性化状態の定義は, 完全弾塑性型の場合, 2 次剛性の状態とし, Tri-Linear 型の場合, 2 次および 3 次剛性の 状態としている。図 12 は, 層数が $N=1,10,20$ のケースについて 各層の $V_{R p}$ の $V_{R}$ に対する比 $\left(V_{R p} / V_{R}\right)$ を示したものである. 図 12 において, $\left(V_{R p} / V_{R}\right)$ が 1.0 の時は, 塑性化状態で最大層間変形角速 度が発生しており，1.0未満の場合は弾性域で最大層間変形角速度 が発生していることを示す。
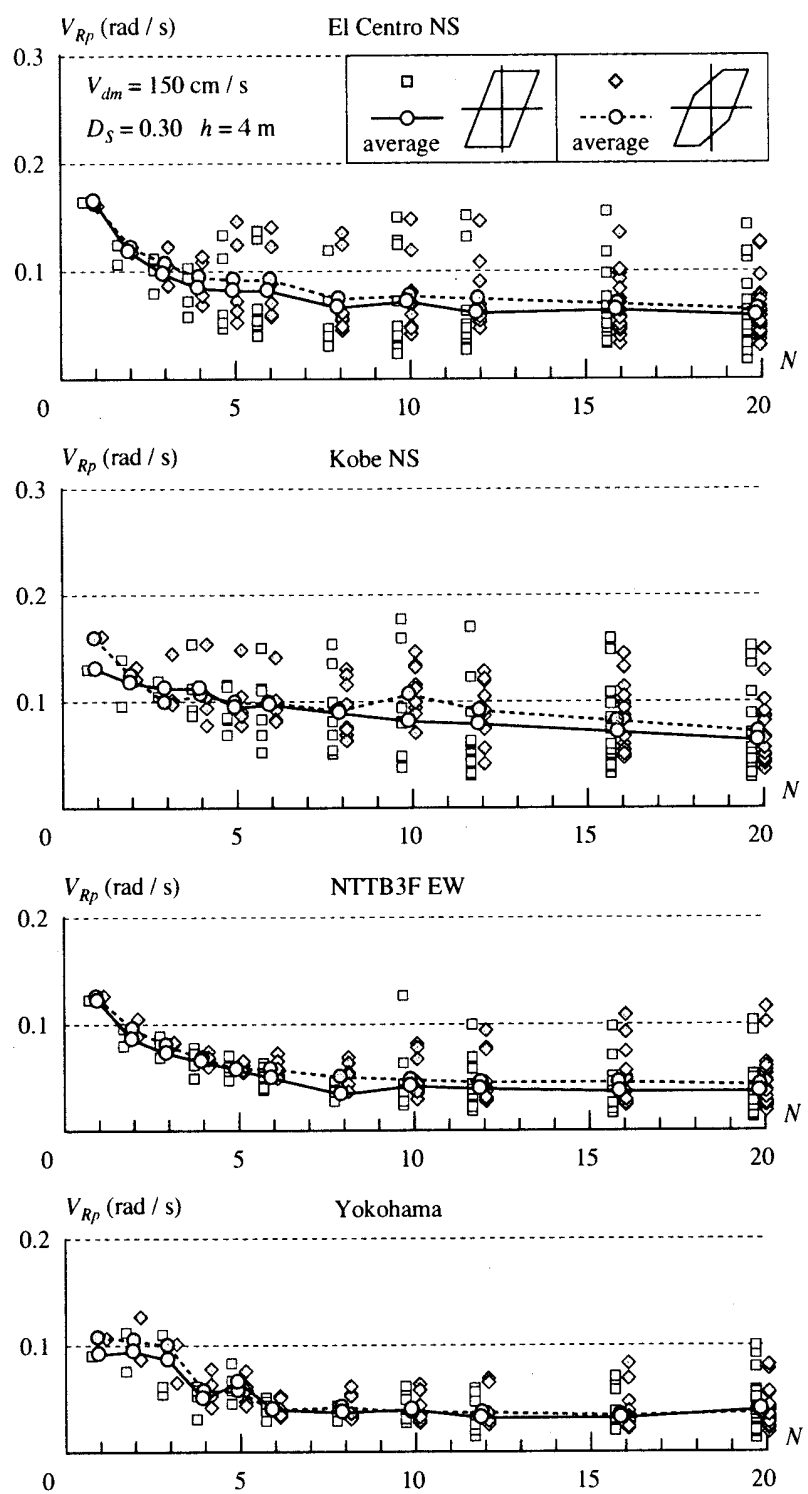

図10 塑性域の最大層間变形角速度の応答と平均値
前述の $V_{R}$ に関する解析結果と比較して，図10～図12に示す結果 から，下記の特徵的事項が指摘される。

1) $V_{R p}$ は $V_{R}$ と比較して, 層数 $N=1$ では $V_{R}$ と同程度の値となって いるが，層数 $N$ が大きいほど小さくなっている (図4, 図10).

2) $V_{R p}$ は, $V_{R}$ と同様, 損傷に寄与する地震入力エネルギーが大き いほど大きくなっているが，系の耐カレベルにはほとんど影響 されない（図11）。

3）多質点系の場合，下層部および上層部では，塑性域または塑性
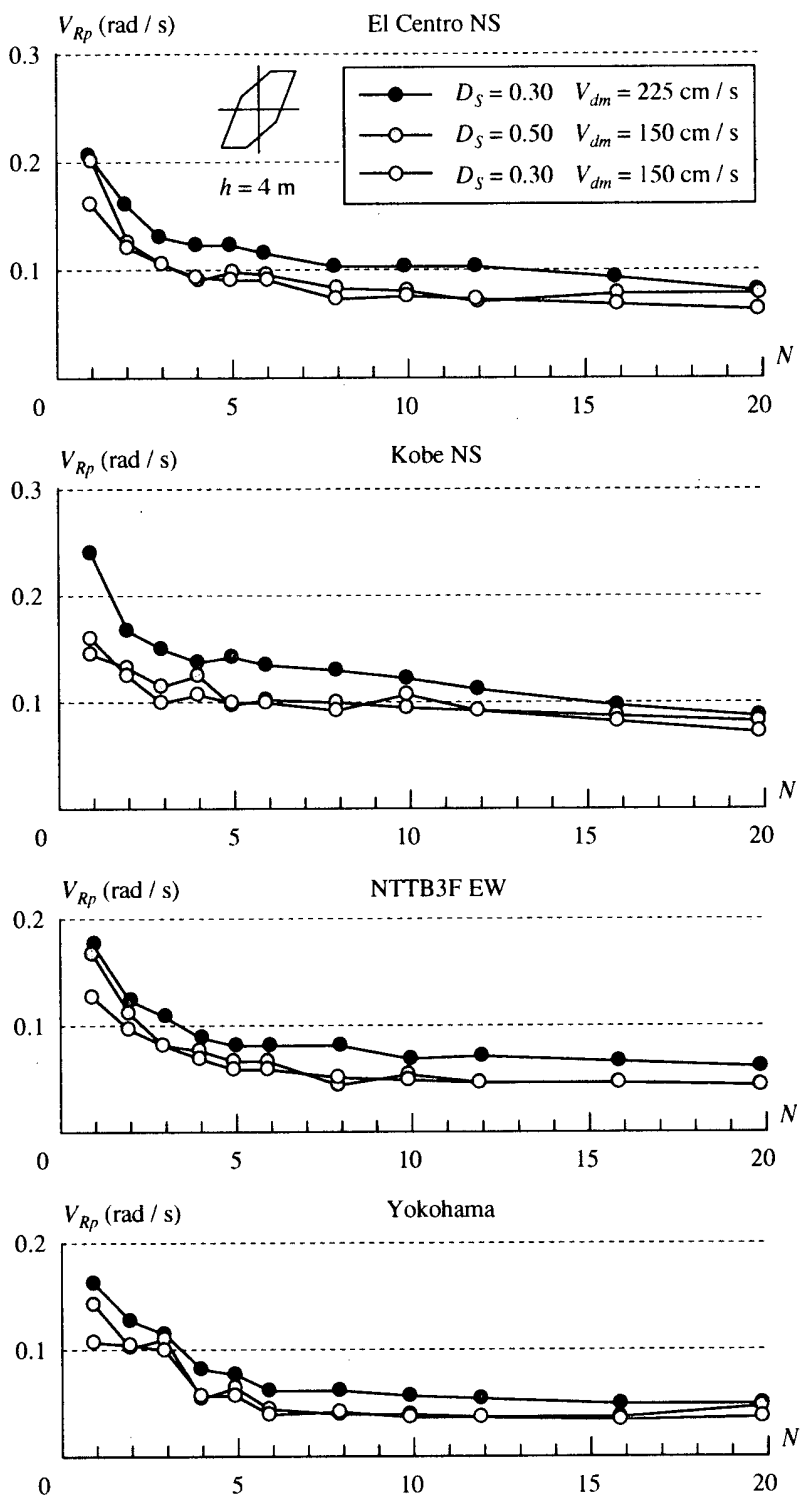

図11 塑性域の最大層間変形角速度の平均値の比較

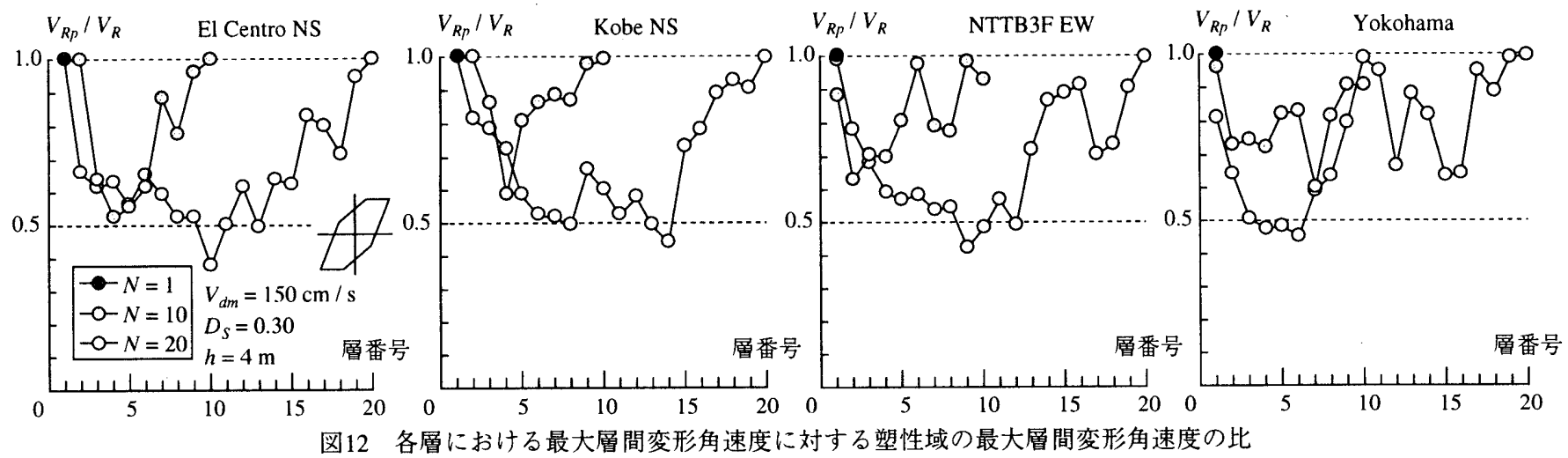


域に近い状態で最大層間変形角速度が発生しているが, 中間層 では弾性域で発生している場合が多く， $V_{R p}$ は $V_{R}$ の $50 \%$ 程度に なっている(図12).

\section{3. 最大層間変形角速度の評価}

\section{1 評価方法}

前章では，最大層間変形角速度応答に関する地震応答解析結果 を示した，本章ではこの応答值に関して理論的検討を行い，応 答解析結果と比較する。

$N$ 質点系の弾塑性構造物において，各質点に発生する運動エネル ギーの和の最大值を $E_{\max }^{k}$ とし，これが損傷に奇与する地震入力エ ネルギー $E_{d m}$ の $r$ 倍であるとする.

$$
E_{\text {max }}^{k}=r E_{d m}=r \frac{M V_{d m}^{2}}{2}
$$

ここでは, 各層の階高 $h$ と質量 $m$ が等しい多質点系を対象と し，次の仮定を設ける。

[1] 各層の最大層間变形速度 $V_{S}$ は等しい.

[2] i番目の質点の最大速度は, それより下の最大層間変形速度の 二乗和平方根で表される。

[3] 系全体の運動エネルギーの最大値は各質点の最大運動エネル ギーの単純和で表される。

図13に, 各層の最大層間变形速度応答値 $V_{S}$ の解析結果を示す. 各解析結果とも $V_{S}$ は上層部で大きくなっているが, 平均值の倍程 度以下であり，ほほ一様であるとみなせる。これが坂定[1]の根拠 である.

各層の最大層間変形速度や各質点の最大速度は同時に生じな い. 仮定[2]はこの非同時性を考慮したものである．各質点系の最 上部質点の最大速度の解析值と計算値を図 14 に示す。計算値は, 各質点についてそれより下の最大層間変形角速度の応答値の二乗
和平方根の值である，両者はほほ同程度の値となっており，仮定 [2]も妥当であると考えられる，仮定[3]は1次のモードが卓越する ものと考えて設定したものである。

仮定[1]，[2]より，i番目の質点の最大速度 $V_{u i}$ は次式で表され る。

$$
V_{u i}=\sqrt{\sum_{j=1}^{i} V_{S}^{2}}=\sqrt{i} V_{S}
$$

次に仮定[3]から， $N$ 質点系の最大運動エネルギー $E_{\text {max }}^{k}$ は次式のよ うに得られる。

$$
E_{\text {max }}^{k}=\sum_{i=1}^{N} \frac{m V_{u i}^{2}}{2}=\frac{m V_{S}^{2}}{2} \sum_{i=1}^{N} i
$$

ここで,

$$
\sum_{i=1}^{N} i=\frac{N(N+1)}{2}, M=m N
$$

であるから，(13)式と(11)式を等值し，(14)式を代入することに よって，最大層間変形角速度 $V_{R}$ を与える次式が得られる。

$$
V_{R}=\frac{V_{S}}{h}=\sqrt{\frac{2 r}{N+1}} \frac{V_{d m}}{h}
$$

ここで，(11)式において定義されている $r$ 值を評価する必要があ る。図15は骨組の層せん断力 $(Q)$ 一層間変形 $(\Delta)$ 関係の1回の片振幅 で吸収される弾性歪エネルギー $\Delta E_{e}$ と塑性歪エネルギー $\Delta E_{p}$ を示 しており，1質点弾塑性系では，図15に示す弾塑性歪エネルギーの 最大值とそれが発生するときの運動エネルギーの最大值が近似的 に等しいことが示されている6)。すなわち，次式が成り立つ.

$$
E_{\text {max }}^{k}=\Delta E_{e}+\Delta E_{p \max }
$$

また文献15)によれば，1サイクル当たりの履歴吸収エネルギーと 弾性歪エネルギーの和の最大值 $\Delta E_{\max }$ と総入力エネルギー $E_{7}$ の関 係が次式で与えられている。
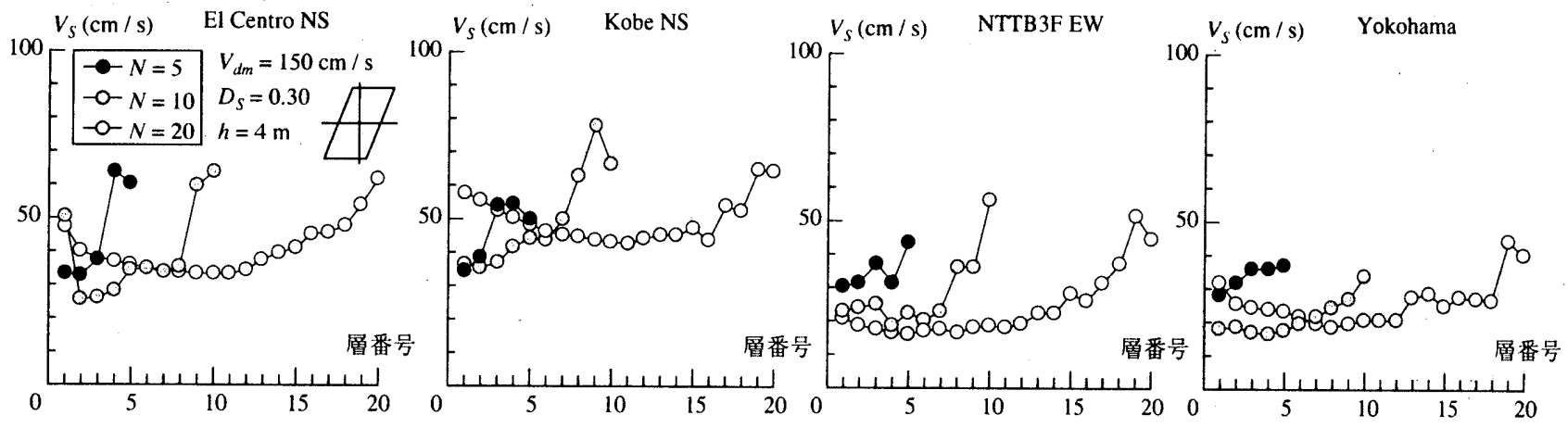

図13＼cjkstart各層における最大層間変形角速度
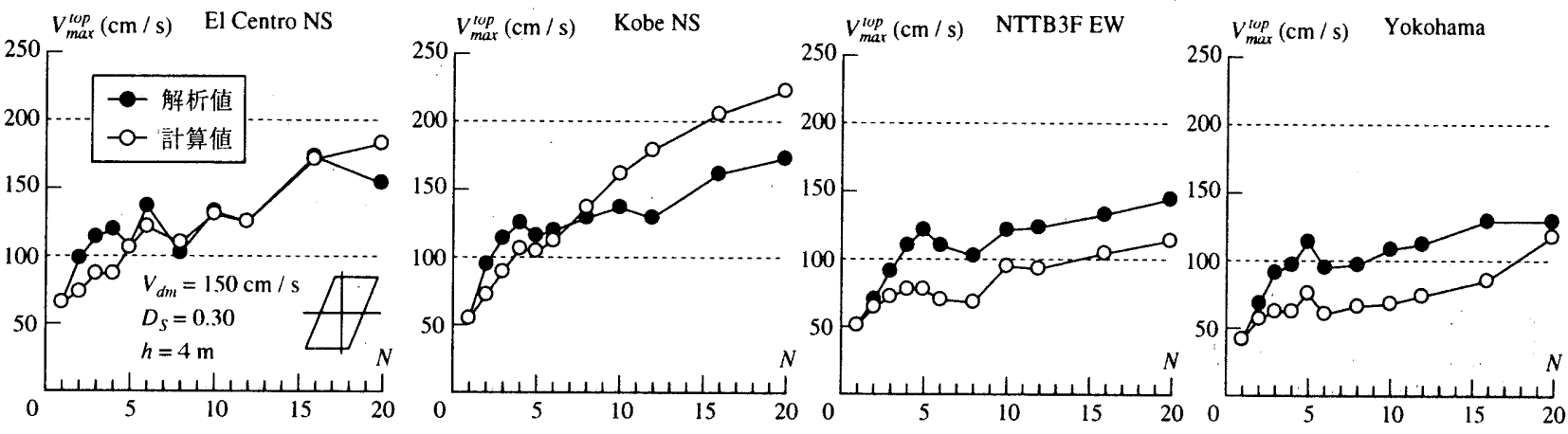

図14 各多質点系の最上部質点の最大速度に関する解析值と計算値 


$$
0.5^{2} \leq \frac{\Delta E_{\max }}{E_{T}} \leq 0.7^{2}
$$

$\Delta E_{\max }$ は次式で表される。

$$
\Delta E_{\max }=\Delta E_{e}+2 \Delta E_{p \max }
$$

$E_{I}$ は減衰による消費エネルギーも含まれているので, (11)式の $E_{d n}$ と同一ではないが，近似的に $E_{T}=E_{d m}$ とみなすと, (11), (16) (18) 式より，次式が得られる。

$$
\frac{1}{2}\left(0.5^{2}+\frac{\Delta E_{e}}{E_{d n}}\right) \leq r \leq \frac{1}{2}\left(0.7^{2}+\frac{\Delta E_{e}}{E_{d n}}\right)
$$

上式の $\left(\Delta E_{e} / E_{d m}\right)$ の項は弾性歪エネルギ一の損傷に寄与する地震 入力エネルギーに対する比であり，ここでは次式のように置く。

$$
\Delta E_{e} / E_{d m}=D_{S}^{2}
$$
さらに， $\Delta E_{p \max }$ は $E_{d n}$ の1/4程度であることが指摘されていて ${ }^{16)}$, これは(19)式における上限值に対応する。本論では,これらの結果 を考慮して $r$ 值を次式で与える。

$$
r=0.25+D_{S}^{2}
$$

(21)式の右辺第1項は塑性歪エネルギーに対応し, 第2項は弾性歪工

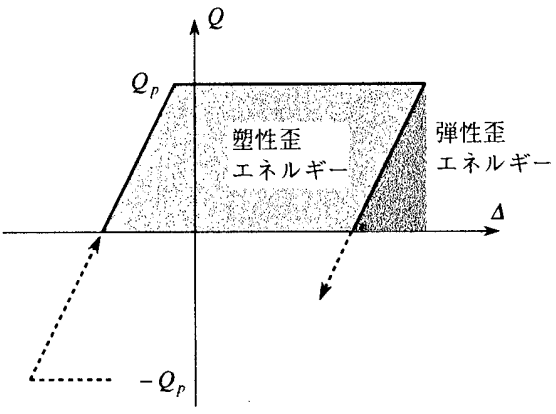

図151回の片振幅で吸収される弾塑性歪エネルギー
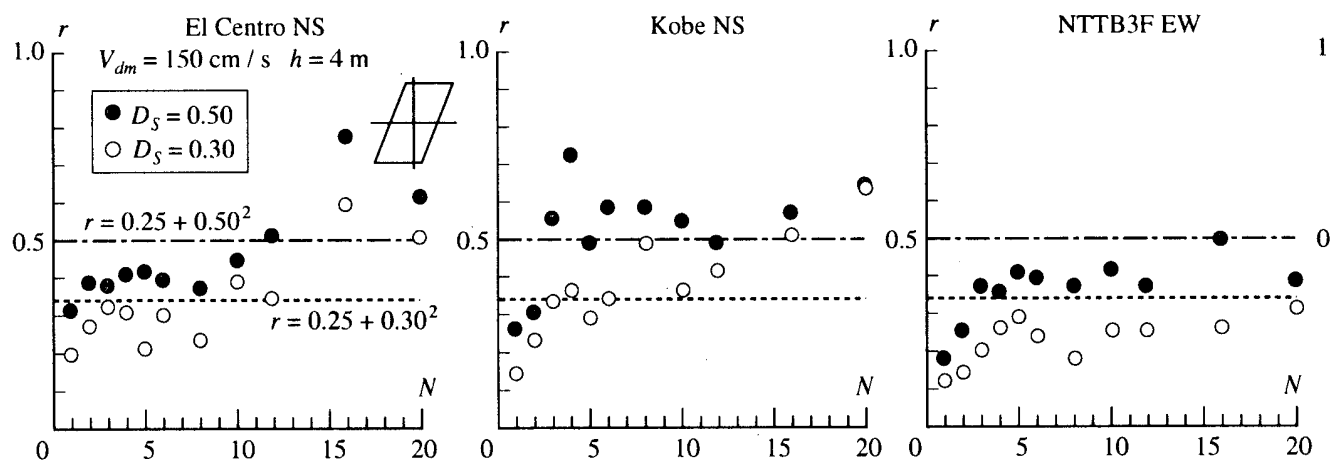

ネルギーに対応する。図16は, 前章の解析結果を用いて(11)式から 得られる $r$ 值をプロットしたものであり, 図中の点線は, (21)式に $D_{S}=0.3$ を代入した值を，一点鎖線は， $D_{S}=0.5$ を代入した値を示 す。当然，同じ $D_{S}$ 值においても，多質点系および地震波の特性に よって $r$ 值は変動しており，(21)式による評価値は, El Centro NSと Kobe NSのr值に対しては平均的な值を, NTTB3FEWとYokohamaに 対しては上限的な值を表す結果となっている。

(15)式と(21)式より, 最大層間変形角速度 $V_{R}$ の推定式が次のよ うに得られる。

$$
V_{R}=\sqrt{\frac{2\left(0.25+D_{S}^{2}\right)}{N+1}} \frac{V_{d m}}{h}
$$

\section{2 忍答解析結果との比較}

(22)式より得られる最大層間変形角速度 $V_{R}$ の計算值を実線で, 応答解析結果（各層の平均值）をプロット点で図17～図19に示 す。応答解析結果については, 本論で採用した地震波に対して応 答值の大きなEl Centro NSとKobe NS，および応答値の小さな Yokohamaについて示している，応答解析結果に対して理論值は質 点数が多くなるにつれて過大から過小評価に移行しているが，全 体的には入力エネルギーの大きさ， $D_{S}$ 值，および階高の影響によ る定性的な応答値の違いを表現している。

\section{4. 結論}

地震時に梁端に発生する歪速度は層間変形角速度と直接関係す る. 本論では, せん断型多質点系の弾塑性地震応答解析を行い, 最大層間変形角速度 $V_{R}$ および塑性域における最大層間変形角速度 $V_{R p}$ に関する解析結果を示した。さらに，最大層間変形角速度 $V_{R}$

図16 損傷に寄与する地震入力エネルギーに対する最大運動エネルギーの比に関する解析値と評価値
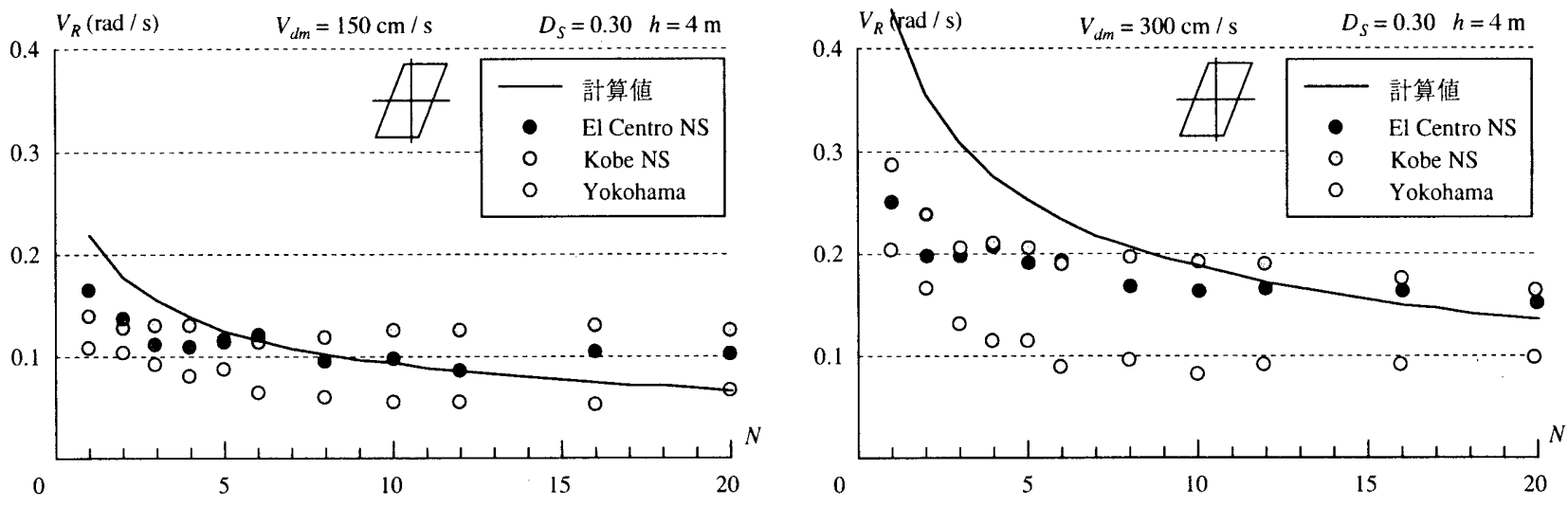

図17 最大層間变形角速度の解析値と評価値（入カレベルの相違の影響） 

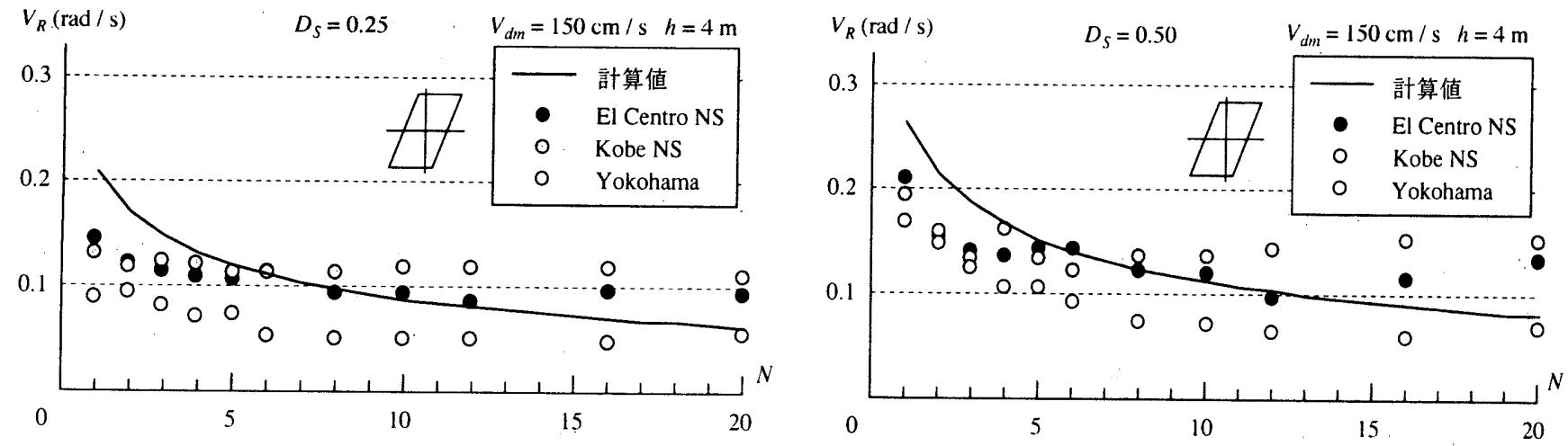

図 18 最大層間変形角速度の解析值と評価値（耐力レベルの相違の影響）
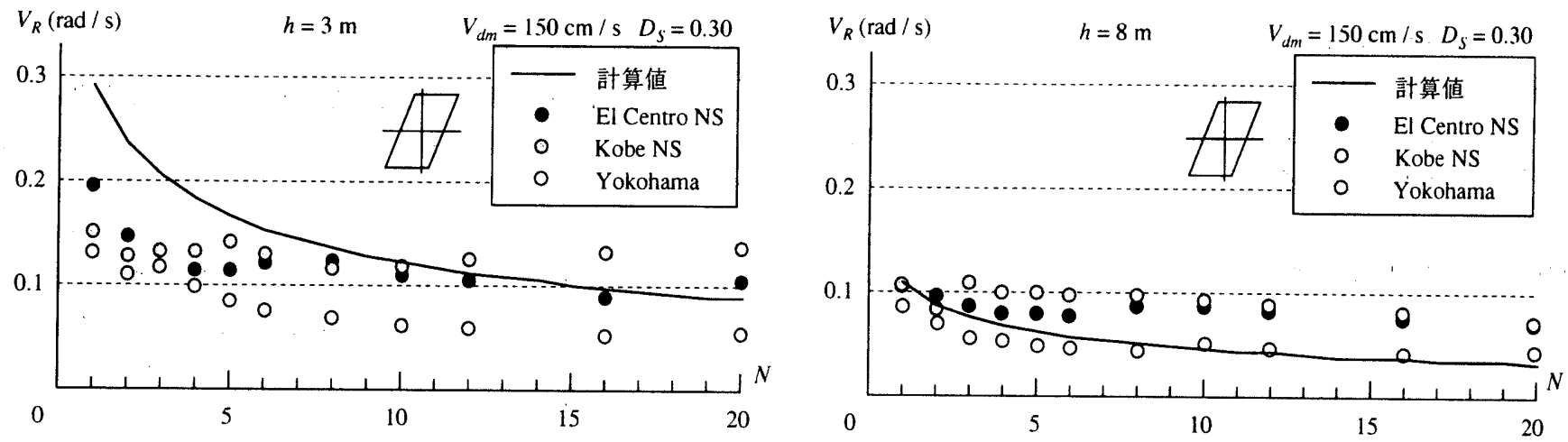

図19最大層間変形角速度の解析值と評価値（階高の影響）

の推定式を誘導し，解析結果との比較を行った。得られた結果は 以下のように要約される.

1) $V_{R}$ は，損傷に寄与する地震入力エネルギーにほほ比例して大き くなり，また層数の増加に伴って漸隇する傾向にある.

2) 加速度パワーが短時間に急激に増大する地震の方が, 徐々に増 大する地震に比べて大きな $V_{R}$ を発生させる。

3） $V_{R}$ は，系の酎力レベルが大きいほど大きくなるが，塑性化領 域における最大層間変形角速度 $V_{R p}$ は, 系の耐カレベルにほと んど影響されない。

4) 系の耐カレベルが $D_{S}$ 值で 0.5 以下の場合, 損傷に寄与する地震 入力エネルギーの速度換算值が $150 \mathrm{~cm} / \mathrm{s}$ の入カレベル（第 2 種地 盤に相当）に対する $V_{R}$ の值は平均で $0.1 \mathrm{rad} / \mathrm{s}$ 程度であり, 高さ 方向の応答のばらつきを含めても高々 $0.2 \mathrm{rad} / \mathrm{s}$ 程度である。

5) 本論で提案した $V_{R}$ の推定式は， $V_{R}$ の概略值を把握する上で有 効である。

\section{謝辞}

本研究は (社) 日本溶接協会 A P D 委員会 (委員長：千葉大学 教授 高梨晃一博士）における研究の一環として行ったものであ る。後指導・後討議いただいた高梨晃一博士，委員諸氏に末筆な がら付記して感謝の意を表する。

付記 本論の数值解析は, 熊本大学教授 小川厚治博士作成のプロ グラム「shearms.f」による

【参考文献】

1）井上一朗，上村健二：多質点弾塑性系の最大層間変形角速度応答，日本建 築学会近畿支部研究報告集, 構造系, pp.257-260, 1997.7.

2）青木博文, 加藤勉; 難波恒夫, 佐藤亘宏 : 変断面鋼板引張材の变形能力に 及ほす試験温度・ひずみ速度の影響，日本建築学会論文報告集，No.322， pp.11-17, 1982.12.
3）寺田岳彦, 矢部喜堂, 真瀨伸治, 坂本真一, 宇野寿郎：動的荷重下におけ る鉄骨柱梁接合部の力学的挙動に関する実験的研究，日本建築学会悽造系 論文集, No.492,pp.121-129, 1997.2.

4）中込忠男, 山田丈富, 中野秀二, 岡希光, 的場耕, 村井正钽：高速載荷に よる柱梁溶接接合部の力学的性能に関する実験的研究, 日本建築学会瑇造 系論文集, No.499,pp.115-122,1997.9

5）田村匠，吹田啓一郎，辻文三：柱梁仕口溶接部の破壊挙動における予歪扔 よび歪速度の影響に関する実験，日本建築学会大会学術講演梗概集C-1棈 造III, pp.367-368, 1997.9.

6）多田元英：1層1スパン鋼骨組の層間变位速度応答に関する考察，日本建築 学会大会学術講演梗概集C-1構造III, pp.745-746, 1996.9.

7) 前田憲太郎，田中淳夫，增田浩志：地震時に銅構造骨組に生じる歪速度， 銅搆造年次論文報告集, 第5卷, pp.423-428，1997.11.

8）日本建筑学会接合小委員会：銅構造接合部の力学性状に関する研究の現状 4.3, 1993.10 .

9) Housner,G.W. : The Plastic Failure of Frame during Earthquake, Proc. of 2WCEE, pp.997-1011, 1960.

10)五十嵐定義, 井上一朗, 永田匡宏：中低層鋼骨組構造物の荷重倸数と崩壊 機構に関する考察（その2.荷重係数と倒壊安全率の関係），日本建篍学会 大会学術講演梗概集，pp.1377-1378，1978.9.

11) 小川厚治：銅構造骨組構成部材の適正强度分布に関する研究，その1.動的 崩壊機構特性とエネルギ一吸收能力，日本建築学会論文報告集，第23号、 pp.13-21, 1983.1.

12) 松島 豊：ホワイトノイズを受ける多自由度系の最適せん断力係数分布, 日本建築学会論文報告集, No.342, pp.22-29, 1984.8.

13）井上一朗，永田匡宏：はり降伏型銅構造骨組の塑性設計用ベースシヤ一保 数に関する研究, 日本建築学会論文報告集, No.305, pp.29-40, 1981.7 .

14) 桑村 保: 耐震建築物の限界状態と破壊規範式, 日本建筑学会構造系論文 報告集，No.342，pp.45-54，1988.5.

15) 日本建築学会：免震構造設計指針5.5.3，pp.88-92，1989.

16) 小川厚治, 黑羽啓明, 待鳥賢治: 强震を受ける1自由度系の正負 2 方向の損 侮分布に関する研究、日本建築学会構造系論文集,No.481,pp.117-126, 1996.3.

(1998年 2 月 10 日原稿受理，1998年 5 月 8 日採用決定) 